\title{
Does Simple Information Provision Lead to More Diverse \\ Classrooms? Evidence from a Field Experiment on \\ Undergraduate Economics ONLINE APPENDIX
}

Amanda Bayer, Syon Bhanot, and Fernando Lozano

January 2019 
Table 1: Average Treatment Effects (Spring 2017)

\begin{tabular}{lccc}
\hline & \multicolumn{3}{c}{ Took Econ - Spring 2017} \\
\cline { 2 - 4 } & $(1)$ & $(2)$ & $(3)$ \\
\hline Welcome & -0.00170 & 0.000615 & -0.00285 \\
& $(0.0185)$ & $(0.0187)$ & $(0.0182)$ \\
Welcome+Info & -0.00805 & -0.00576 & -0.00869 \\
& $(0.0185)$ & $(0.0187)$ & $(0.0183)$ \\
Female & & $-0.0703^{* * *}$ & $-0.0879^{* * *}$ \\
& & $(0.0264)$ & $(0.0268)$ \\
URM & & $-0.0549^{* * *}$ & $-0.0707^{* * *}$ \\
& & $(0.0172)$ & $(0.0182)$ \\
Constant & & & \\
& $0.193^{* * *}$ & $0.271^{* * *}$ & $0.204^{* * *}$ \\
Observations & $(0.0131)$ & $(0.0302)$ & $(0.0318)$ \\
$R^{2}$ & 2710 & 2605 & 2605 \\
School Fixed Effects & 0.000 & 0.004 & 0.068 \\
\hline
\end{tabular}

Notes: This table shows the average treatment effects of the Welcome and Welcome + Info treatment conditions using completion of a Spring 2017 economics course as the outcome variable. These results mirror those in Table 1 in the published paper, but using this different outcome variable. Standard errors are in parentheses. * $\mathrm{p}<0.10 * *$ $\mathrm{p}<0.05 * * * \mathrm{p}<0.01$ 
Table 2: Average Treatment Effects for Subgroups

\begin{tabular}{|c|c|c|c|c|c|c|c|c|}
\hline & \multicolumn{2}{|c|}{ White Women } & \multicolumn{2}{|c|}{ URM Women } & \multicolumn{2}{|c|}{ URM Men } & \multicolumn{2}{|c|}{ First Gen } \\
\hline & $\begin{array}{c}\quad(1) \\
\text { Fall } 2016\end{array}$ & $\begin{array}{c}(2) \\
\mathrm{AY} 16-17\end{array}$ & $\begin{array}{c}\quad(3) \\
\text { Fall } 2016\end{array}$ & $\begin{array}{c}(4) \\
\mathrm{AY} 16-17\end{array}$ & $\begin{array}{c}(5) \\
\text { Fall } 2016\end{array}$ & $\begin{array}{c}(6) \\
\mathrm{AY} 16-17\end{array}$ & $\begin{array}{c}(7) \\
\text { Fall } 2016\end{array}$ & $\begin{array}{c}(8) \\
\text { AY } 16-17\end{array}$ \\
\hline Welcome & $\begin{array}{c}-0.00619 \\
(0.0233)\end{array}$ & $\begin{array}{c}0.0110 \\
(0.0285)\end{array}$ & $\begin{array}{c}0.0146 \\
(0.0286)\end{array}$ & $\begin{array}{r}-0.00110 \\
(0.0395)\end{array}$ & $\begin{array}{c}0.0497 \\
(0.0540)\end{array}$ & $\begin{array}{c}0.0401 \\
(0.0639)\end{array}$ & $\begin{array}{l}-0.0224 \\
(0.0542)\end{array}$ & $\begin{array}{c}0.0532 \\
(0.0690)\end{array}$ \\
\hline Welcome + Info & $\begin{array}{c}0.0184 \\
(0.0240)\end{array}$ & $\begin{array}{c}0.00985 \\
(0.0285)\end{array}$ & $\begin{array}{c}0.0337 \\
(0.0303)\end{array}$ & $\begin{array}{c}-0.000322 \\
(0.0403)\end{array}$ & $\begin{array}{c}0.0790 \\
(0.0548)\end{array}$ & $\begin{array}{c}0.0365 \\
(0.0643)\end{array}$ & $\begin{array}{c}0.114^{*} \\
(0.0635)\end{array}$ & $\begin{array}{c}0.114 \\
(0.0703)\end{array}$ \\
\hline Female & & & & & & & $\begin{array}{c}-0.198^{* * *} \\
(0.0634)\end{array}$ & $\begin{array}{c}-0.221^{* * *} \\
(0.0739)\end{array}$ \\
\hline URM & & & & & & & $\begin{array}{c}-0.207^{* * *} \\
(0.0720)\end{array}$ & $\begin{array}{c}-0.229^{* * *} \\
(0.0803)\end{array}$ \\
\hline Constant & $\begin{array}{c}0.0793^{* * *} \\
(0.0192)\end{array}$ & $\begin{array}{l}0.150^{* * *} \\
(0.0251)\end{array}$ & $\begin{array}{l}0.137^{* * *} \\
(0.0512)\end{array}$ & $\begin{array}{l}0.193^{* * *} \\
(0.0591)\end{array}$ & $\begin{array}{c}0.0996 \\
(0.0621)\end{array}$ & $\begin{array}{l}0.310^{* * *} \\
(0.0870)\end{array}$ & $\begin{array}{l}0.424^{* * *} \\
(0.0928)\end{array}$ & $\begin{array}{c}0.489^{* * * *} \\
(0.107)\end{array}$ \\
\hline Observations & 1411 & 1411 & 625 & 625 & 336 & 336 & 222 & 222 \\
\hline$R^{2}$ & 0.036 & 0.082 & 0.010 & 0.019 & 0.039 & 0.019 & 0.096 & 0.068 \\
\hline School Fixed Effects & Yes & Yes & Yes & Yes & Yes & Yes & Yes & Yes \\
\hline
\end{tabular}

Notes: This table shows the average treatment effects of the Welcome and Welcome+Info treatment conditions, for various subgroups (White women, URM women, URM men, and first gen students). Results are shown for each subgroup, for the completion of a Fall 2016 economics course outcome variable ("Fall 2016") and for completion of any economics course at some point in the 2016-17 academic year ("AY 16-17"). All regressions include controls as appropriate. Note that the first gen regressions (columns 7-8) include students from only four schools - those where first gen data was available. Standard errors are in parentheses. ${ }^{*} \mathrm{p}<0.10 * * \mathrm{p}<0.05 * * * \mathrm{p}<0.01$ 


\section{Treatment 1 - Welcome}

\section{Email \#1}

Congratulations on your decision to attend [YOUR College]! We in the Economics Department welcome you and would like to get to know you over the next four years. We hope that you start by taking [Econ \#, NAME, LINK] in the coming year.

- Sincerely,

Professor [NAME], on behalf of the Economics Department

\section{Email \#2}

Welcome to campus! We are excited you are here! We encourage you to explore courses across campus, and we especially hope to see you in [Econ \#, NAME, LINK].

Best wishes for a great semester,

Professor [NAME], on behalf of the Economics Department 


\section{Treatment 2 - Welcome+Info}

Figure 2: Welcome+Info Treatment Email Content

\section{Email \#1}

Congratulations on your decision to attend [YOUR College]! We in the Economics Department welcome you and would like to get to know you over the next four years. We hope that you start by taking [Econ\#, NAME, LINK] in the coming year. Please click on the images below to learn a bit about what economists do and the kinds of things you can investigate with the tools you or learn in economics courses.

\section{Sincerely,}

Professor [NAME], on behalf of the Economics Department

\section{Email \#2}

Welcome to campus! We are excited you are here! We encourage you to explore courses across campus, and we especially hope to see you in [Econ \#, NAME, LINK]. Please click on the images to learn some more about economists and their research.

Best wishes for a great semester,

Professor [NAME], on behalf of the Economics Department 
Figure 3: Welcome+Info Treatment Email \#1 Detailed Content

\section{Welcome+Info treatment - First email info}

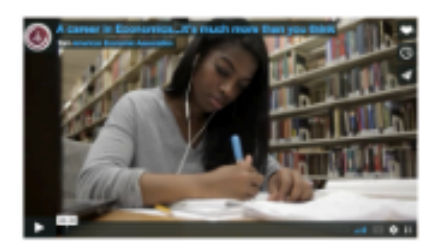

\section{Economics...it's much more than you think ...Es mucho más de lo que piensas}

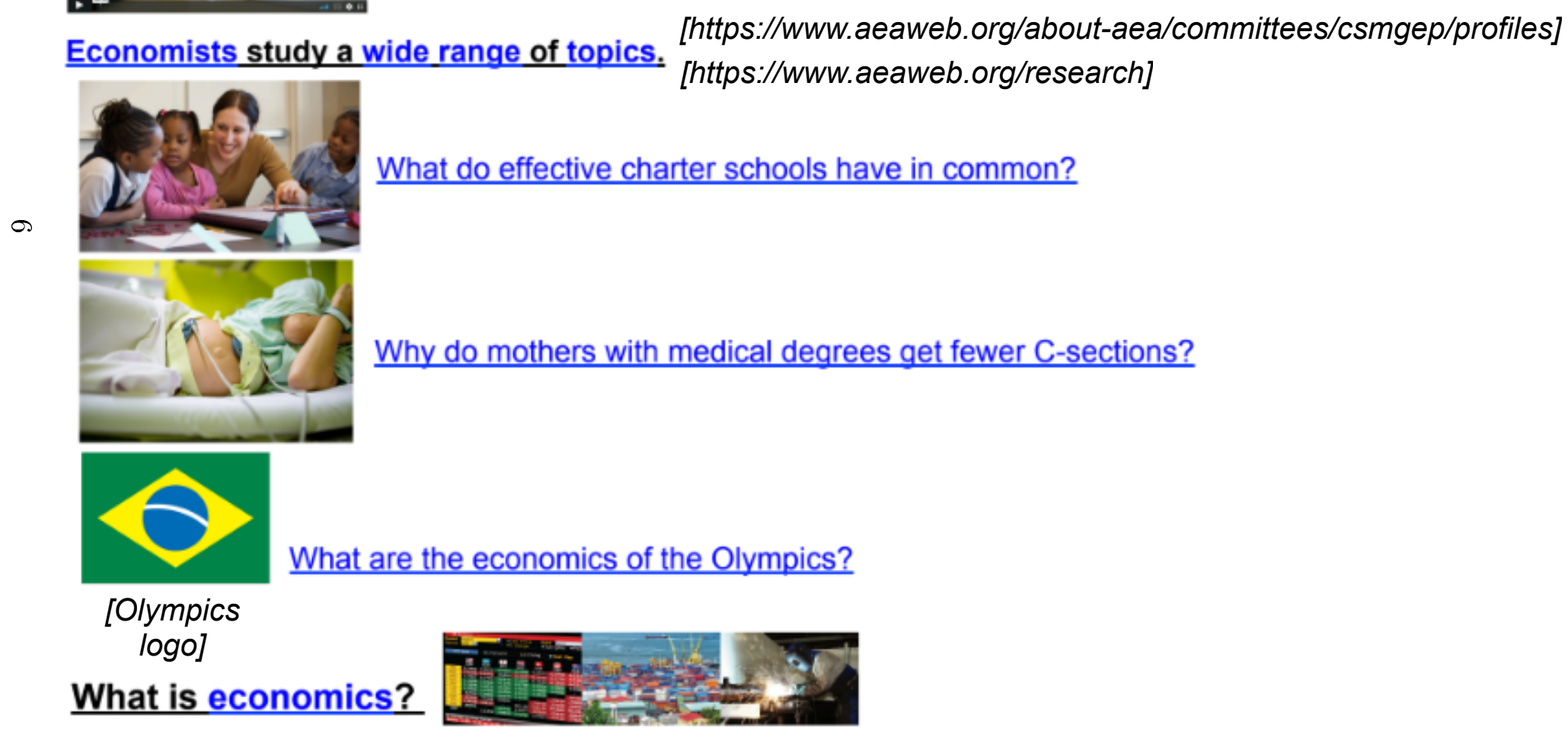

[Copyright American Economic Association; reproduced with permission of the AEA]. 


\section{Figure 4: Welcome+Info Treatment Email \#2 Detailed Content Welcome+Info treatment - Second email info}

Meet Some Economists:

Lashawn Richburq-Haves, Senior Research Associate, MDRC

"My own neighborhood is always at the back of my mind."

Mark Hugo Lopez, Director of Hispanic Research, Pew Research Center

"I should have had more confidence in myself...Nothing happens unless you make it happen. You aren't sought; you have

to seek."

Janet L. Yellen, Chair of the Board of Governors of the Federal Reserve System

"When economics is tested by future challenges, I hope that our profession will be able to say that we have done all we could to attract the best people and the best ideas."

Bookmark the American Economic Association's: Resources for Students

Explore a wide range of topics:

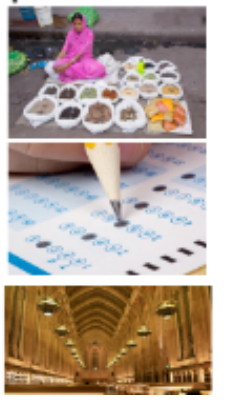

Can strong peer networks close the gender gap in entrepreneurship?

Can a nearby SAT test center boost college attendance?

Do employers frown on for-profit colleges and online degrees?

[Copyright American Economic Association; reproduced with permission of the AEA]. 